\title{
Pelestarian Khazanah Terbitan Daerah Melalui Layanan Deposit: Implementasi Undang-Undang Nomor 13 tahun 2018
}

\author{
Alda Amalia Nur Islamiati, Athiatul Haqqi \\ Universitas Islam Negeri Sulthan Thaha Saifuddin Jambi, Indonesia \\ Jalan Jambi - Muaro Bulian Km.16, Muaro Jambi, 36363 \\ e-mail:aldaamalia98@gmail.com
}

\begin{abstract}
Introduction. This article discusses the role of the Jambi Provincial Library and Archives Service (DPAD) in preserving regional publications through deposit services. The purpose of this study was to find out the implementation of Law Number 13 of 2018 on the Jambi Province Regional Deposit Collection at the Jambi Province DPAD, to find out the obstacles faced by the Jambi Province DPAD deposit service in implementing Law Number 13 of 2018 concerning the Handover of Printed and Printed Works. Recording work. Research methods. This research uses descriptive qualitative method. Collecting data using observation, interview, and documentation techniques. Data analysis. Data analysis techniques used are data reduction, data presentation, and drawing conclusions. Then the data triangulation technique was carried out. Results and Discussion. The results of this study indicate that the implementation of Law Number 13 of 2018 carried out by the Jambi Province DPAD Deposit Service is socializing, sending letters, carrying out hunting activities and providing lending services and reading services on the spot and giving warning letters to publishers who do not implement the Act. Law Number 13 of 2018. The obstacles faced are the lack of awareness of the publishers and the absence of strict sanctions against publishers, the library is less aware of the existence of private public publishers in the area. Conclusions and suggestions. The implementation of Law Number 13 of 2018 in the Jambi Province DPAD has been implemented but has not been effective. It is better to have more routine socialization regarding the contents of Law Number 13 of 2018.
\end{abstract}

Keywords: Deposit Service, Law Number 13 of 2018

\begin{abstract}
ABSTRAK
Pendahuluan. Artikel ini membahas tentang Peran Dinas Perpustakaan dan Arsip Daerah (DPAD) Provinsi Jambi dalam melestarikan khazanah terbitan daerah melalui layanan deposit. Tujuan Penelitian ini adalah untuk mengetahui Implementasi Undang-Undang Nomor 13 tahun 2018 terhadap Koleksi Deposit Daerah Provinsi Jambi pada DPAD Provinsi Jambi, untuk mengetahui kendala yang dihadapi layanan deposit DPAD Provinsi Jambi dalam implementasi Undang-Undang Nomor 13 tahun 2018 tentang Serah Simpan Karya cetak dan Karya rekam. Metode penelitian. Penelitian ini menggunakan metode kualitatif deskriptif. Pengumpulan data menggunakan teknik observasi, wawancara, dan dokumentasi. Data analisis. Teknik analisis data yang digunakan adalah reduksi data, penyajian data, dan penarikan kesimpulan. Kemudian dilakukan teknik triangulasi data. Hasil dan pembahasan. Hasil penelitian ini menunjukkan bahwa Implementasi Undang-Undang Nomor 13
\end{abstract}


tahun 2018 yang dilakukan oleh Layanan Deposit DPAD Provinsi Jambi yaitu sosialisasi, pengiriman surat, melaksanakan kegiatan hunting dan memberikan jasa peminjaman dan layanan baca di tempat dan memberi surat teguran kepada penerbit yang tidak melaksanakan Undang-Undang Nomor 13 tahun 2018. Kendala yang dihadapi yaitu kurangnya kesadaran dari pihak penerbit dan tidak adanya sanksi tegas kepada penerbit, pihak perpustakaan kurang mengetahui adanya penerbit umum swasta yang ada di daerah. Kesimpulan dan Saran. Implementasi Undang-Undang Nomor 13 tahun 2018 di DPAD Provinsi Jambi sudah dilaksanakan namun belum berjalan efektif. Sebaiknya sosialisasi lebih rutin lagi tentang isi dari Undang-Undang Nomor 13 tahun 2018.

Kata Kunci : Layanan Deposit, Undang-Undang Nomor 13 tahun 2018

\section{A. PENDAhULUAN}

Indonesia merupakan negara yang memiliki beraneka ragam suku,budaya,bahasa, dan adat istiadat. Keanekaragaman ini merupakan suatu ciri khas dari Negara Indonesia, maka dari itu perlunya pelestarian agar kekayaan yang dimiliki Indonesia dapat dirasakan oleh generasi muda. Hal ini merupakan suatu tanggung jawab untuk setiap individu. Dengan perkembangan zaman, keanekaragaman yang dimiliki Indonesia dibuat dalam bentuk karya cetak maupun non cetak agar dapat lebih mudah dalam pelestarian dan pengolahannya.

Lembaga yang berwenang dalam melestarikan dan mengolah suatu karya cetak maupun non cetak adalah perpustakaan, melalui perpustakaan segala jenis informasi tersebut mengenai hasil karya manusia dari suatu daerah, wajib disimpan di perpustakaan, sedangkan untuk karya cetak dan karya rekam yang terbit dari daerah masing-masing yang mengelolanya adalah bagian bidang deposit. Tugas utama bidang deposit adalah melestarikan bahan pustaka dan mengumpulkan penerbitan di Indonesia maupun di luar negeri tentang Indonesia (Sulasmansyah, 2016). Karya cetak maupun non cetak yang ada di bidang deposit tersebut harus dikelola dengan baik agar informasi di dalamnya dapat terjaga dan memudahkan dalam temu kembali informasi.

Pentingnya pelestarian karya budaya bangsa di undangkan dalam Undang-Undang RI Nomor 13 Tahun 2018 dalam poin b menyebutkan: 
"Bahwa karya cetak dan karya rekam yang merupakan hasil budaya bangsa memiliki peran penting sebagai salah satu tolak ukur kemajuan intelektual bangsa, referensi dalam bidang pendidikan, perkembangan ilmu pengetahuan dan teknologi, penelitian dan penyebaran informasi, dan pelestarian kebudayaan nasional, serta merupakan alat telusur terhadap catatan sejarah, jejak perubahan, dan perkembangan bangsa untuk pembangunan dan kepentingan nasional.”

Alasan memilih Dinas Perpustakaan dan Arsip Daerah Provinsi Jambi karena hanya ada di DPAD yang ada layanan deposit dan Badan Perpustakaan Provinsi ini sebagai sarana yang membantu Gubernur dalam penyelenggaraan Pemerintah di bidang pendidikan, penelitian, bidang ilmu pengetahuan, teknologi dan penyebaran informasi serta pelestarian hasil budaya bangsa, dimana tujuan pelaksanaan Undang-Undang ini adalah untuk mengumpulkan dan menyimpan hasil karya cetak dan karya rekam terbitan dari suatu daerah khususnya Jambi sebagai upaya untuk mewujudkan koleksi daerah yang lengkap dan dapat memenuhi kebutuhan pengguna.

Undang-undang deposit telah direvisi dan telah diterapkan oleh Dinas Perpustakaan dan Arsip Daerah Provinsi Jambi namun dalam kenyataannya sebagian besar penerbit yang ada di Daerah Jambi belum memberikan respons yang positif, karena tidak semua penerbit yang ada di Jambi menyerahkan hasil terbitannya kepada Dinas Perpustakaan dan Arsip Daerah Provinsi Jambi bidang deposit. Jika ditinjau dari isi undang-undang deposit tersebut yang menyatakan bahwa layanan deposit ini berisikan koleksi daerah Jambi dan hasil terbitan dari penerbit yang ada di daerah Jambi. Tetapi dalam kenyataannya layanan deposit Dinas Perpustakaan dan Arsip Daerah Provinsi Jambi ini didominasi koleksi dari terbitan pemerintah/instansi.

Dinas Perpustakaan dan Arsip Daerah Provinsi Jambi ini tidak mengetahui jumlah penerbit yang ada di Provinsi Jambi ini, dilihat dari observasi ke setiap rak di bidang deposit DPAD untuk karya cetak lebih dominan Terbitan Pemerintah, Surat Kabar dan Skripsi sedangkan untuk karya rekam berbentuk CD dan kaset, jumlah koleksi yang ada di layanan deposit tersebut sebanyak 10.354 eksemplar (DPAD Prov.Jambi, 2019). Permasalahan selanjutnya yaitu pihak perpustakaan tidak ada memberi Sanksi yang jera kepada penerbit yang tidak menyerahkan karya cetak dan karya rekam kepada perpustakaan. Pihak perpustakaan hanya memberikan sebuah peringatan kepada penerbit yang tidak patuh pada peraturan serah simpan karya cetak dan karya rekam tersebut. 


\section{B. KAJIAN TEORI}

\section{Implementasi}

Menurut Guntur Setiawan (2004) dalam bukunya yang berjudul Implementasi Dalam Birokrasi Pembangunan mengemukakan bahwa implementasi adalah perluasan aktivitas yang saling menyesuaikan proses interaksi antara tujuan dan tindakan untuk mencapainya serta memerlukan jaringan pelaksana, birokrasi yang efektif.

Implementasi adalah aktivitas atau usaha-usaha yang dilakukan untuk semua rencana dari kebijakan yang telah dirumuskan dan ditetapkan, dan di lengkapi segala kebutuhan alat-alat yang diperlukan, siapa yang melaksanakan, dimana tempat pelaksanaannya, kapan waktu pelaksanaannya, kapan waktu dimulai dan berakhirnya dan bagaimana cara yang harus dilakukan (Pariata, 1989).

Jadi, dari beberapa penjelasan di atas dapat disimpulkan bahwa implementasi adalah suatu tindakan atau usaha yang telah direncanakan agar tercapainya suatu kegiatan.

\section{Undang- Undang Nomor 13 Tahun 2018 tentang Serah Simpan Karya Cetak dan}

\section{Karya Rekam ( Deposit).}

Undang-Undang ini mengatur pelaksanaan serah simpan karya cetak dan karya rekam yang dimulai dari penyerahan karya cetak dan karya rekam, pengelolaan hasil serah simpan karya cetak dan karya rekam, pendanaan, peran serta masyarakat, dan penghargaan.

Dalam Undang- Undang Nomor 13 tahun 2018 memiliki 8 BAB dengan 36 Pasal. Pada BAB I berisikan tentang ketentuan umum seperti penjelasan mengenai pengertian karya cetak dan karya rekam dan penjelasan mengenai fungsi adanya Undang-Undang No.13 tahun 2018 tersebut, sedangkan BAB II tentang penyerahan karya cetak dan karya rekam pasal 4 ayat 1 dan 4 menyebutkan “ Setiap penerbit wajib menyerahkan 2 (dua) eksemplar dari setiap judul karya cetak kepada Perpustakaan Nasional dan 1 (satu) eksemplar kepada Perpustakaan Provinsi tempat domisili penerbit. Penyerahan karya cetak sebagaimana dimaksud pada ayat (1) dilakukan paling lama 3 ( tiga) bulan setelah diterbitkan." Sedangkan pada BAB II 
Pasal 7 ayat 1 dan 4 menyebutkan bahwa " Setiap penerbit yang tidak melaksanakan kewajiban sebagaimana dimaksud dalam pasal 4 mendapatkan pembinaan dari Perpustakaan Nasional atau Perpustakaan Provinsi. Dan jika Penerbit tidak melaksanakan kewajibannya dalam jangka waktu sebagaimana dimaksud pada ayat (3) dikenai sanksi administratif berupa:

a. Teguran tertulis

b. Pembekuan kegiatan usaha; dan/atau

c. Pencabutan izin.

BAB III tentang pengelolaan hasil serah simpan karya cetak dan karya rekam dimulai dari penerimaan, pengadaan, pencatatan, pengolahan, penyimpanan, pendayagunaan, pelestarian dan pengawasan. BAB VI tentang Pendanaan. Dana yang dimaksud di sini mengenai dana yang bersumber dari anggaran pendapatan dan belanja negara, anggaran pendapatan dan belanja daerah atau dana lain yang sah dan tidak mengikat sesuai dengan ketentuan peraturan perundang-undangan.

BAB V tentang peran serta masyarakat yang mana maksudnya adalah "masyarakat" orang perseorangan, kelompok orang, organisasi masyarakat, badan usaha atau badan hukum. Untuk menyerahkan koleksi pribadinya kepada perpustakaan nasional dan perpustakaan provinsi untuk dijadikan koleksi serah simpan. BAB VI tentang Penghargaan, perpustakaan nasional maupun perpustakaan provinsi memberikan penghargaan kepada penerbit yang telah melaksanakan kewajibannya, selain penerbit penghargaan diberikan juga kepada masyarakat yang telah berperan dalam mendukung kewajiban serah simpan.

Kewajiban serah simpan karya cetak dan karya rekam tidak hanya ditunjukkan kepada penerbit atau pengusaha rekaman yang menghasilkan karya cetak dan karya rekam di dalam Negeri, tetapi ditunjukkan pula kepada setiap warga Negara Indonesia yang berbagai pertimbangan menerbitkan karya-karyanya baik dalam bentuk cetak atau pun rekaman (Sulistyo-Basuki, 1994).

Dengan adanya Undang-Undang Tentang Serah Simpan Karya Cetak dan Karya Rekam ini dimaksudkan untuk menumbuhkan kesadaran penerbit dan produsen karya rekam untuk menyerahkan karya cetak dan karya rekam sehingga dapat menyelamatkan karya cetak dan karya rekam. 


\section{Jenis- Jenis Layanan}

Layanan perpustakaan adalah salah satu kegiatan teknis yang pada pelaksanaannya perlu adanya perencanaan dalam penyelenggaraannya (Rahmah, 2018).

Pada umumnya pelayanan yang diselenggarakan perpustakaan umum adalah pelayanan sirkulasi, pelayanan referensi, pelayanan audiovisual, pelayanan terbitan berseri, pelayanan anak, pelayanan deposit. Dari keenam jenis layanan tersebut, penulis hanya menguraikan mengenai layanan deposit.

Satu tugas dan fungsi Perpustakaan Nasional adalah "sebagai pusat deposit terbitan nasional dalam melaksanakan Undang-Undang Nomor 4 Tahun 1990 tentang serah simpan karya cetak dan karya rekam". Berdasarkan undang- undang tersebut, Perpustakaan Nasional dan Perpustakaan Nasional Provinsi mendapat tugas untuk melakukan penghimpunan, penyimpanan, dan pelestarian bahan karya cetak dan karya rekam yang dihasilkan di wilayah Indonesia.

\section{Layanan Deposit}

Menurut Sari, layanan deposit merupakan layanan perpustakaan yang mengumpulkan, menyimpan dan melestarikan terbitan suatu daerah dan tentang daerah tersebut untuk dimanfaatkan oleh pemustaka.

Koleksi deposit adalah koleksi yang terdiri dari bahan pustaka yang diterbitkan di wilayah Provinsi dan pustaka yang berisi informasi tentang berbagai aspek dan mengenai wilayah Provinsi yang diterbitkan di luar maupun di dalam wilayah Provinsi. Koleksi deposit dihasilkan dari hasil serah simpan karya cetak atau karya rekam yang telah diatur dalam Undang-Undang No. 13 Tahun 2018.

\section{Pengertian Perpustakaan Umum}

Perpustakaan Umum adalah perpustakaan yang diselenggarakan oleh dana umum dengan tujuan untuk melayani masyarakat. Perpustakaan umum adalah perpustakaan yang dibiayai dari dana umum, baik sebagian maupun seluruhnya, terbuka untuk umum tanpa membeda-bedakan usia, jenis kelamin, kepercayaan, agama , ras, pekerjaan, keturunan, serta memberikan layanan cuma-cuma untuk masyarakat umum (Sulistyo-Basuki, 1994: 35). Sedangkan dalam Undang-Undang No. 43 Tahun 2007 dalam pasal 1 ayat 6 bahwa "Perpustakaan umum adalah perpustakaan yang 
diperuntukkan bagi masyarakat luas sebagai sarana pembelajaran sepanjang hayat tanpa membedakan umum, jenis kelamin, suku, ras, agama, dan status sosialekonomi."

Perpustakaan umum merupakan lembaga pendidikan yang dinyatakan sangat demokratis karena menyediakan sumber belajar sesuai dengan kebutuhan masyarakat, dan melayaninya tanpa membedakan suku bangsa, agama yang dianut, jenis kelamin, latar belakang, dan tingkat sosial, umur dan pendidikan, serta perbedaan lainnya (NS, 2003).

Dari beberapa penjelasan di atas dapat disimpulkan bahwa perpustakaan umum adalah perpustakaan yang dibuka untuk umum yang diselenggarakan dari dana umum untuk sarana pembelajaran bagi seluruh masyarakat tanpa kecuali.

\section{METODOLOGI}

Penelitian ini dilakukan di Dinas Perpustakaan dan Arsip Daerah Provinsi Jambi. Ada pun jenis penelitian ini adalah kualitatif dengan pendekatan deskriptif. Peneliti menggunakan metode ini untuk mendapatkan gambaran dan pemahaman mengenai implementasi Undang-Undang No. 13 tahun 2018, hambatan dan upaya yang dilakukan dalam implementasi UU No. 13 tahun 2018 di DPAD.

Penelitian ini menggunakan jenis dan sumber data di mana jenis data yang digunakan data kualitatif dan sumber data dalam penelitian ini adalah data primer dan data sekunder.

Subjek penelitian merupakan metode yang digunakan untuk menentukan subjek atau individu yang dapat memberikan informasi atau keterangan terkait dengan permasalahan yang akan diteliti (Sugiyono, 2017). Pada penelitian ini menggunakan teknik Purposive sampling yaitu teknik penentuan informan melalui beberapa pertimbangan tertentu. Key Informan penelitian ini adalah Kepala Dinas Perpustakaan dan informan yang lainnya adalah pihak yang terlibat dalam implementasi UU No. 13 tahun 2018 tentang serah simpan karya cetak dan karya rekam, sebanyak 3 informan dari pihak perpustakaan dan 2 informan dari pihak penerbit.

Metode pengumpulan data yang digunakan dalam penelitian ini menggunakan tiga cara sebagai berikut: 


\section{Pengamatan ( Observasi)}

Observasi atau sering disebut juga sebagai pengamatan adalah suatu kegiatan pemusatan perhatian terhadap sesuatu dengan menggunakan mata (Sugiyono, 2008: 310). Dengan mengamati secara langsung penulis mendapat informasi mengenai implementasi UU No.13 tahun 2018 di DPAD Provinsi Jambi.

2. Wawancara

a. Wawancara Terstruktur

Wawancara terstruktur digunakan sebagai teknik pengumpulan data oleh peneliti atau pengumpul data bila mereka mengetahui dengan pasti tentang apa yang akan diperoleh (Sugiyono, 2012).

b. Wawancara Tidak Terstruktur

Wawancara tidak struktur merupakan wawancara yang berbeda dengan yang restruktur. Menurut Moleong wawancara tidak struktur merupakan pelaksanaan tanya jawab mengalir seperti dalam percakapan sehari-hari (Moleong, 2014).

\section{Dokumentasi}

Penulis menggunakan metode ini untuk mengumpulkan dokumen-dokumen yang berhubungan dengan data penelitian.

Analisis data proses mencari dan menyusun secara sistematis data yang diperoleh dari hasil wawancara, catatan lapangan, dan bahan-bahan lain sehingga dapat mudah dipahami, dan temuannya dapat diinformasikan kepada orang lain (Sugiyono, 2008: $317)$.

Teknik analisis yang digunakan dalam penelitian ini menggunakan deskriptif kualitatif. Menganalisis data merupakan proses pengolahan data yang ada kemudian hasilnya disimpulkan berupa penilaian yang mengarah pada predikat yang dimaksud berupa hasil yang dinyatakan dengan kualitas yang baik, cukup baik, atau kurang baik sesuai tujuan penelitian (Soebani, 2008). Setelah data terkumpulkan tahap selanjutnya adalah menganalisis data seperti yang telah dikemukakan oleh Miles dan Hubermen yang mencakup :

\section{Reduksi Data (Data Reduction)}

Reduksi data yakni proses pemilihan, pemusatan perhatian pada penyederhanaan, pengabstraksian, dan transformasi data kasar yang muncul dari 
catatan-catatan yang tertulis di lapangan (Rum: 17). Mereduksi data berarti merangkum, memilih hal-hal yang pokok, memfokuskan pada hal-hal penting, mencari tema dan polanya, dengan demikian data yang telah direduksi akan memberikan gambaran yang lebih jelas, dan mempermudah penelitian untuk mengumpulkan data selanjutnya (Fitriyanti, 2016: 19).

2. Penyajian Data ( Data Display)

Penyajian data, diuraikan sebagai sekumpulan informasi tersusun yang memberikan kemungkinan adanya penarikan kesimpulan dan pengambilan tindakan. Dengan penyajian data wawancara terstruktur digunakan sebagai teknik pengumpulan data oleh peneliti atau pengumpul data bila mereka mengetahui dengan pasti tentang apa yang akan diperoleh (Sugiyono, 2012), peneliti akan dapat memahami apa yang terjadi dan apa yang dilakukan berdasarkan pemahaman tentang penyajian.

3. Menarik Kesimpulan

Pada tahap penarikan kesimpulan, peneliti sudah membuat kategori-kategori, mencatat keterangan,pola-pola, penjelasan konfigurasi-konfigurasi yang mungkin alur sebab akibat dan proposisi.

\section{PEMBAHASAN}

\section{Implementasi Undang-Undang Nomor 13 Tahun 2018}

a. Sosialisasi Undang-Undang Nomor 13 tahun 2018 tentang serah simpan karya cetak dan karya rekam.

Mengenai sosialisasi UU Nomor 13 tahun 2018 di Dinas Perpustakaan dan Arsip Daerah Provinsi Jambi, kegiatan sosialisasi yang dilakukan setiap satu tahun sekali oleh Dinas Perpustakaan dan Arsip Daerah Provinsi Jambi hanya dihadiri oleh penerbit-penerbit instansi/pemerintah dan percetakan dari surat kabar, sehingga pihak penerbit swasta umum tidak pernah mengikuti sosialisasi yang diadakan oleh Dinas Perpustakaan dan Arsip Daerah Provinsi Jambi, dikarenakan kurangnya pendekatan dengan pihak penerbit umum swasta. 


\section{b. Prosedur Implementasi Undang-Undang Nomor 13 tahun 2018 tentang serah simpan karya cetak dan karya rekam}

Dalam pelaksanaan penerapan Undang-Undang tersebut terdapat prosedur dalam pelaksanaan serah simpan karya cetak dan karya rekam pada Dinas Perpustakaan dan Arsip Daerah Provinsi Jambi.

\section{a. Pengiriman Surat}

Dinas Perpustakaan dan Arsip Daerah Provinsi Jambi telah melakukan pengiriman surat ke setiap penerbit instansi/pemerintah seperti yang telah diatur Instruksi Gubernur dan Undang-Undang.

\section{b. Hunting}

Hunting ini merupakan kegiatan penjemputan koleksi yang dilakukan oleh pihak layanan deposit Dinas Perpustakaan dan Arsip Daerah Provinsi Jambi. Saat penjemputan koleksi itu tidak hanya koleksi karya anak daerah saja tapi koleksi yang berisikan tentang daerah Provinsi Jambi, kegiatan hunting ini juga dilakukan tidak hanya di dalam daerah tetapi di luar daerah juga tujuannya untuk mencari koleksi tentang Provinsi Jambi.

\section{c. Penerimaan dan Pencatatan Hasil Karya Cetak dan Karya Rekam}

Pihak perpustakaan pun menerima hasil karya cetak dan karya rekam melalui kiriman langsung dari penerbit ataupun penerbit mengirimkan nya menggunakan jasa pengirim, tahap selanjutnya petugas layanan deposit pun menginventarisasikan hasil karya cetak dan karya rekamnya dan di buat buku laporan sebagai bukti untuk penerbit yang telah menyerahkan hasil cetakannya kepada perpustakaan

\section{d. Pelayanan dan Peminjaman}

Dinas Perpustakaan dan Arsip Daerah Provinsi melayankan koleksi deposit dengan mempersilahkan kepada pemustaka untuk memanfaatkan koleksi deposit dengan menelusuri sendiri ke setiap rak atau dapat dikatakan bahwa layanan deposit Dinas Perpustakaan dan Arsip Daerah Provinsi Jambi yaitu layanan sistem terbuka, karena pemustaka dapat menelusuri sendiri koleksi yang di carinya, tetapi tidak untuk dibawa pulang 


\section{Hambatan dalam mengimplementasi Undang-Undang serah simpan karya cetak} dan karya rekam.

Setiap lembaga atau organisasi pasti selalu terdapat masalah dalam menjalankan tugas dan fungsinya. Seperti di perpustakaan banyak sekali permasalahan yang dihadapi dalam memberikan informasi kepada pemustaka, hampir setip perpustakaan memiliki permasalahan yang sama atau tidak jauh berbeda.

Dinas Perpustakaan dan Arsip Daerah Provinsi Jambi belum menjalankan sanksi yang telah ditentukan dalam Undang-Undang No. 13 tahun 2018 sebagaimana mestinya. Meskipun sanksi yang disebutkan pada Undang-Undang Nomor 13 tahun 2018 pada BAB II Pasal 7 ayat (4) bahwa sanksi tersebut untuk para penerbit yang tidak melaksanakan wajib serah simpan karya cetak dan karya rekam dikenai sanksi administrasi berupa teguran, pembekuan kegiatan usaha atau pencabutan izin, tapi kenyataannya tidak berjalan efektif sesuai peraturan yang telah ditetapkan. Dinas Perpustakaan dan Arsip Daerah Provinsi Jambi hanya menjalankan sanksi pada poin ke 1 saja yaitu berupa teguran dan peringatan saja.

3. Upaya dalam mengimplementasikan Undang-Undang serah simpan karya cetak dan karya rekam

Seperti yang telah diungkapkan di atas dalam mengimplementasikan UndangUndang Nomor 13 tahun 2018 ini terdapat beberapa kendala yang dihadapi oleh Dinas Perpustakaan dan Arsip Daerah Provinsi Jambi, maka dari itu perlu adanya upaya untuk mengatasinya agar tujuan dalam proses implementasi Undang-Undang Nomor 13 tahun 2018 dapat berjalan sesuai yang diinginkan.

Dinas Perpustakaan dan Arsip Daerah Provinsi Jambi belum ada upaya untuk kendala pemberian sanksi yang tegas. Sebaiknya Dinas Perpustakaan dan Arsip Daerah Provinsi Jambi perlu memberikan sanksi yang tegas kepada penerbit yang tidak menyerahkan hasil cetaknya, seperti yang telah dicantumkan dalam UndangUndang Nomor 13 tahun 2018 agar penerbit sadar dan segara menyerahkan hasil cetakannya kepada perpustakaan. 


\section{E. KESIMPULAN}

Berdasarkan hasil temuan penelitian dan pembahasan yang telah diuraikan pada bab IV, penulis mengambil kesimpulan:

1. Implementasi Undang-Undang Nomor 13 tahun 2018 di Dinas Perpustakaan dan Arsip Daerah Provinsi Jambi sudah berjalan namun belum berjalan secara efektif jika dipersenkan hanya $80 \%$ yang telah terlaksana, dikarenakan terdapat beberapa kendala yang dihadapi oleh perpustakaan dalam pelaksanaan Undang-Undang tersebut, dari pihak perpustakaan pun kurang mengetahui penerbit umum swasta maka dari itu pihak penerbit umum swasta tidak pernah ikut dalam sosialisasi yang selalu pihak perpustakaan adakan, dalam pelaksanaan Undang-Undang Nomor 13 tahun 2018 ini perpustakaan mempunyai prosedur agar pelaksanaan berjalan sesuai tujuan. Dimana prosedur tersebut telah disebutkan dalam Undang-Undang Nomor 13 tahun 2018 pada BAB III diantaranya seperti: 1). Mengirim surat 2). Hunting 3). Penerimaan dan pencatatan hasil karya cetak dan karya rekam dan 4). Sistem pelayanan dan peminjaman. Semua prosedur tersebut telah dilaksanakan sesuai peraturan Undang-Undang Nomor 13 tahun 2018 tersebut.

2. Hambatan yang dihadapi oleh pihak perpustakaan dalam Implementasi UndangUndang Nomor 13 tahun 2018 ini di antaranya kurang kesadaran dari pihak para wajib serah simpan untuk menyerahkan hasil cetakan kepada perpustakaan dan pihak perpustakaan kurang mengetahui mengenai penerbit umum swasta, dan kendala selanjutnya adalah belum adanya sanksi yang tegas dari pihak perpustakaan untuk para wajib serah simpan yang tidak menyerahkan hasil cetakannya kepada perpustakaan sehingga pihak penerbit tidak antusias dalam melaksanakan Implementasi Undang-Undang Nomor 13 tahun 2018 tersebut.

3. Upaya yang dilakukan oleh Dinas Perpustakaan dan Arsip Daerah Provinsi Jambi dalam Implementasi Undang-Undang Nomor 13 tahun 2018 di antaranya:1). Rutin mengadakan sosialisasi setiap tahunnya, 2). Melaksanakan kegiatan hunting untuk mengambil hasil cetakan dari pihak penerbit dengan mendatangi pihak penerbit tersebut, 3). Memberikan Penghargaan kepada penerbit yang rajin dan rutin menyerahkan hasil cetakannya kepada perpustakaan. 


\section{Saran}

1. Sebaiknya Dinas Perpustakaan dan Arsip Daerah Provinsi Jambi perlu melakukan sosialisasi lebih rutin lagi dan selalu memberi himbauan dan pemahaman tentang isi dari Undang-Undang Nomor 13 tahun 2018 dan Peraturan Pemerintah kepada para wajib serah simpan. Dengan begitu pelakasanaan Undang-Undang Nomor 13 tahun 2018 dapat berjalan dengan maksimal.

2. Hendaknya Dinas Perpustakaan dan Arsip Daerah Provisni Jambi perlu memperhatikan juga pihak penerbit umum swasta agar penerbit umum swasta dapat mengetahui jika ada kegiatan sosialisasi yang dilaksanakan perpustakaan.

3. Sebaiknya Dinas Perpustakaan dan Arsip Daerah Provinsi Jambi perlu melakukan kerja sama dengan pihak-pihak penegakan hukum agar pemberian sanksi yang tegas dapat berjalan sesuai aturan Undang-Undang tersebut.

\section{DAFTAR PUSTAKA}

Anwar, S., Maskur, S., \& Jailani, M. 2019. Manajemen Perpustakaan. Riau: Indragiri Dot Com.

Fitriyanti.2016. Implementasi Undang-Undang Nomor 4 Tahun 1990 Tentang Serah Simpan Karya Cetak dan Karya Rekam (Deposit) di Badan Perpustakaan Provinsi Sumatera Selatan (Tahun 2006-2015). 19.

Guntur Setiawan. 2004. Implementasi dalam Birokrasi Pembangunan. Jakarta: Balai Pustaka.

Lasa,HS.1990. Kamus Istilah Perpustakaan . Yogyakarta: Kanusius. .2009. Kamus Kepustakwanan Indonesia . Yogyakarta: Pustaka Book Publisher.

Moleong. J.L. 2014. Metodologi Penelitian Kualitatif. Bandung: Remaja Rosdakarya.

Nasution, R. S.2018. Implementasi Undang-Undang Nomor 4 Tahun 1990 Terhadap Koleksi Deposit Sumatera Utara pada Dinas Perpustakaan dan Arsip Daerah Provinsi Sumatera Utara.

Nazir, M.2011. Metode Penelitian. Bogor: Ghalia Indonesia.

Nurdin Usman. 2002. Konteks Implementasi Berbasis Kurikulum. Jakarta: Grasindo.

Rahmah, Elva. 2018. Akses dan Layanan Perpustakaan : teori dan aplikasi. Jakarta: Prenadamedia Group. 
Rimbarawa, K., \& Supriyanto.2006. Aksentuasi Perpustakaan dan Pustakawan. Jakarta: Sagung Seto.

Rum, M. Desain Penelitian Kualitatif dan Kuantitatif dalam Ilmu Perpustakaan dan Informasi.

Sari, Arianti Permata. Layanan Pusat Deposit Bahan Pustaka dalam Memenuhi Kebututuhan Informasi.

Soebani, Beni Ahmad .2008. Metode Penelitian Kualitatif . Jakarta: Rineka Cipta.

Sugiyono. 2012. Metode Penelitian Pendidikan Pendekatan Kualitatif, Kuantitatif, R dan D. Bandung: Alfabeta.

Sugiyono. Metode Penelitian Pendidikan : Pendekatan Kuantitatif, Kualitatif dan R\&D.2017

Sukma, G. M., \& Suliyati, T.2016. Optimalisasi Perpustakaan Daerah Jawa Tengah dalam Penerapan Undang-Undang No.4 Tahun 1990 Tentang Serah Simpan Karya Cetak Karya Rekam di Provinsi Jawa Tengah Tahun 2011-2015. 2.

Sulasmansyah, M. A.2016. Peran BAPUSIPDA dalam Implementasi Undang-Undang Nomor 04 Tahun 1990 Tentang Serah Simpan Karya Cetak dan Karya Rekam. Bandung: Universitas Pendidikan Bandung.

Sulistyo-Basuki. 1991. Pengantar Ilmu Perpustakaan. Jakarta: Gramedia Pustaka Utama.

Sulistyo-Basuki. Periodisasi Perpustakaan Indonesia. Bandung: Remaja Rosdakarya, 1994

Sutarno,NS.2006. Manajemen Perpustakaan : Suatu Pendekatan Praktik. Jakarta: Sagung Seto.

Sutarno,NS. 2003. Perpustakaan dan Masyarakat. Jakarta: Yayasan Obor Nasional RI.

Undang-Undang Republik Indonesia Nomor 13 Tahun 2018 Tentang Serah Simpan Karya Cetak dan Karya Rekam. 2018. Jakarta.

Undang-Undang Republik Indonesia Nomor 43 Tahun 2007 Tentang Perpustakaan. 2007. Jakarta.

Pedoman Penulisan Proposal dan Skripsi Fakultas Adan dan Humaniora. 2018. Jambi: Fakultas Adab dan Humaniora UIN STS Jambi.

Profil Dinas Perpustakaan dan Arsip Daerah Provinsi Jambi tahun 2019.2019. Jambi: Dinas Perpustakaan dan Arsip Daerah Provinsi Jambi.

Westra Pariata. 1989. Ensiklopedia Administrasi. Jakarta: Gunung Agung. 